\title{
OBITUARY
}

\section{PROFESSOR OSWALDO PAULO FORATTINI}

(1924-2007)

\section{On September $15^{\text {th }}, 2007$, Brazil lost one of its leading Public Health Scientists, Professor Oswaldo Paulo Forattini (83 years old), in São Paulo, Brazil.}

Professor Forattini was the only child of Italian immigrants, who arrived in Brazil in the early 1920s. He grew up in a multilingual environment, speaking Italian and French with his mother, Portuguese with his father and in school. He studied Latin, and ultimately became fluent in Portuguese, Spanish, French, Italian, and English.

Prof. Forattini had a passionate interest in literature, history, classical music and arts. As a teenager he wanted to study history, but other interests influenced his decision to study medicine after completing high school. He studied medical science in the Faculdade de Medicina, Universidade de São Paulo. During this time he rapidly became involved in tropical medicine research. He published six articles while he was a student in 1946, another five papers in 1947, and was awarded in recognition of his scholarly work entitled Esquistossomose Mansônica em Santos, Estado de São Paulo (Schistosomiasis mansoni in Santos, São Paulo State), which was presented as part of the discipline Cadeira de Higiene da Faculdade de Medicina. Upon leaving medical school in 1949, he embarked on medical entomology studies with John Lane in 1950 and public health studies in 1957 while employed as an assistant professor in the Department of Parasitology and Rural Hygiene, Faculdade de Saúde Pública. In 1959, he became an adjunct professor in the same department, a position he held until 1967 when the administrative framework of the university was restructured. As a consequence, Prof. Forattini transformed the Department of Epidemiology, and became "Professor Catedrático" and chairman for several years.

Prof. Forattini had a very productive scientific life in addition to his enormous contributions toward the development of the university and science in Brazil. Briefly, he was the Director of Faculdade de Saúde Pública, Chairman of the Department of Epidemiology, and Coordinator of the Núcleo de Pesquisas Taxonômica e Sistemática em Entomologia Médica. In addition to his noteworthy participation in the Editorial Board of Editora da Universidade de São Paulo, he was the founder and first editor of Revista de Saúde Pública, he established the Sistema Integrado de Bibliotecas (SIBI) of the Universidade de São Paulo, and was Counselor of Fundação de Amparo à Pesquisa do Estado de São Paulo.

His numerous outstanding scientific contributions to the development of medical entomology in Brazil and Latin America include studies on Ceratopogonidae, Triatominae, Phlebotominae, Culicidae and Cimicidae. He investigated various aspects of the biology of insects of medical importance, including taxonomy, bionomics, distribution, ecology,

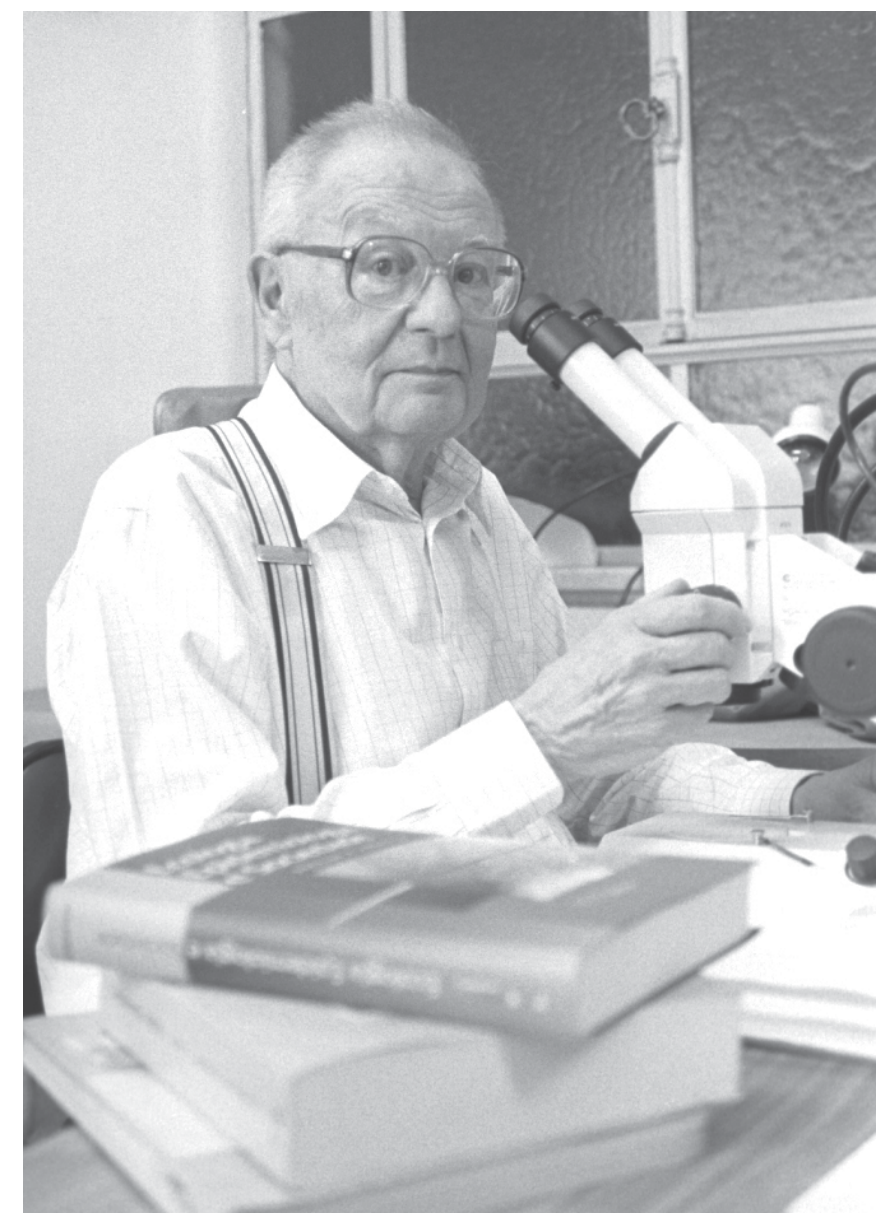

morphology, behavior, control, and others. As a consequence, Prof. Forattini published more than 200 scientific articles on different subjects in medical entomology and tropical medicine in collaboration with his students and colleagues from Brazil and other countries. As an epidemiologist and medical entomologist, he also wrote 27 editorials dealing with various subjects of public health interest. Additionally, he published 13 books and 2 book chapters, some of which are considered classic treatments, especially his four volumes dealing with medical entomology in the Neotropical Region:

Forattini, O.P. - Entomologia médica. Parte geral, Diptera, Anophelini. v. 1, São Paulo, Faculdade de Saúde Pública da USP, 1962.

Forattini, O.P. - Entomologia médica. Culicini: Culex, Aedes e Psorophora. v. 2, São Paulo, Ed. da Universidade de São Paulo, 1965.

Forattini, O.P. - Entomologia médica. Culicini: Haemagogus, Mansonia, Culiseta, Sabethini, Toxorhynchitini, Arboviroses, Filariose bancroftiana, Genética. v. 3, São Paulo, Ed. da Universidade de São Paulo, 1965.

Forattini, O.P. - Entomologia médica. Psychodidae, Phlebotominae, Leishmanioses, Bartonelose. v. 4, São Paulo, Ed. Edgard Blücher/Ed. Univ. S.Paulo, 1973. 
All illustrations in the four books were drawn by Prof. Forattini himself. He was a passionate medical entomologist who worked long hours every day, including weekends, to complete his books. With a pencil, a sharpener, an old typewriter and an old fashioned art pen, he skillfully drew the illustrations for his books. Prof. Forattini wrote two books on Epidemiology, and prepared $2^{\text {nd }}$ editions of both.

Prof. Forattini was a great speaker and had the ability to stimulate and impassion his audiences. The courses he taught in "Ecology in Public Health" were powerful and unforgettable. His lectures began with a specific subject, were expanded from a world perspective, and were artfully concluded with reference to the opening subject. In fact, his classes were an amazing trip through the world of biology, public health and medicine.

As a natural consequence of a very productive life, Prof. Forattini received a number of prestigious awards in recognition of his outstanding contributions, including Emílio Ribas Award (1947); José Pinto Alves Award (1948); "Relevant Contribution for Research" Award, Universidade de São Paulo (1992); "John Belkin Memorial” Award, American Mosquito Control Association, USA (1995); Jabuti Award for his books
Culicidologia Médica. Vol. 1. (1996) and "Câmara Brasileira do Livro" Award (1997).

Without doubt, however, his most important legacy is the immense number of undergraduate and graduate students and researchers he educated, whom will further his studies and greatly enhance our understanding of Brazilian mosquitoes. It is important to point out that the majority of his students are actively working as researchers and professors in various universities and research institutes in Latin America.

Professor Forattini left his wife Maria Teresinha Dias de Andrade, son Eduardo Paulo de Andrade Forattini, daughter-in-law Nathalia Berton Kohlmann and granddaughter, Giulia.

Maria Anice Mureb Sallum, Departamento de Epidemiologia, Faculdade de Saúde Pública, Universidade de São Paulo, Brazil.

Ralph E. Harbach, Department of Entomology, The Natural History Museum, London, U.K.

Bruce A. Harrison, NC DENR, Division of Environmental Health, Public Health Pest Management Section. Winston-Salem, NC. U.S.A. 